\title{
RELEVANSI MATERI TATA UDARA DI SMK DAN DI DPTM DENGAN STANDAR KOMPETENSI KERJA NASIONAL INDONESIA
}

\author{
Aditya Prabowo ${ }^{1}$, Kamin Sumardi², Maman Rakhman ${ }^{3}$ \\ Departemen Pendidikan Teknik Mesin \\ Universitas Pendidikan Indonesia \\ Jl. Dr. setiabudhi No. 207 Bandung 40154 \\ masaditya12@gmail.com
}

\begin{abstract}
ABSTRAK
Penelitian ini bertujuan untuk memperoleh seberapa besar tingkat relevansi materi teknik tata udara di Departemen Pendidikan Teknik Mesin dengan materi tata udara di SMK, seberapa besar tingkat relevansi materi tata udara di SKKNI bidang kompetensi tata udara dengan materi tata udara di Departemen Pendidikan Teknik Mesin dan seberapa besar tingkat relevansi materi tata udara di SKKNI bidang kompetensi tata udara di SMK. Metode yang digunakan dalam adalah dengan memaparkan ke dalam bentuk tabel, membuat grafik tingkat relevansi dan pembahasan data. Hasil penelitian ini menunjukan materi tata udara di Departemen Pendidikan Teknik Mesin dan di SMK dengan SKKNI memiliki nilai relevansi sebesar $100 \%$.
\end{abstract}

Kata Kunci: relevansi, kompetensi, tata udara, SKKNI.

\section{PENDAHULUAN}

Sekolah Menengah Kejuruan (SMK) merupakan sebuah lembaga pendidikan kejuruan formal yang didirikan oleh pemerintah sebagai salah satu upaya untuk mempersiapkan anak bangsa agar mampu bersaing di Dunia Usaha atau Dunia Industri (DU/DI). Seperti yang tercantum dalam Undang-Undang Dasar Negara Republik Indonesia No.20 tahun 2003 tentang sistem pendidikan nasional pasal 18 dijelaskan bahwa pendidikan kejuruan merupakan pendidikan menengah yang mempersiapkan peserta didik terutama untuk bekerja pada suatu bidang tertentu. PP 29 tahun 1990 Pasal 1 ayat 3 menjelaskan pendidikan kejuruan adalah pendidikan pada jenjang menengah yang mengutamakan pengembangan kemampuan siswa untuk melaksanakan jenis pekerjaan tertentu. Berdasarkan tujuan pendidikan menengah kejuruan tersebut, artinya siswa lulusan SMK harus memiliki kompetensi yang sesuai dengan Standar Kompetensi Kerja Nasional Indonesia (SKKNI) sehingga siswa lulusan SMK dapat terserap dengan baik oleh dunia kerja (Kemendiknas, 2103). Berdasarkan Permendiknas no 70 tahun 2013, mulai tahun ajaran 2013/2014 SMK akan menggunakan kurikulum 2013.

\footnotetext{
${ }^{1}$ Mahasiswa Departemen Pendidikan Teknik Mesin FPTK UPI

${ }^{2}$ Dosen Departemen Pendidikan Teknik Mesin FPTK UPI

${ }^{3}$ Dosen Departemen Pendidikan Teknik Mesin FPTK UPI
} 
Penerapan kurikulum 2013 di SMK diharapkan dapat menjadi solusi untuk memecahkan permasalahan tersebut. Kurikulum 2013 perlu ditunjang dengan berbagai elemen penting, salah satu elemen penting tersebut adalah guru karena guru terlibat langsung dalam Proses Belajar Mengajar (PBM). Guru berperan penting dalam peningkatan kualitas pembelajaran di kelas. Guru mempunyai hak sepenuhnya untuk mengelola kelas agar setiap materi yang akan disampaikan dapat dipahami dan dimengerti oleh peserta didik (Nasution, 2008). Guru tidak hanya berperan sebagai penyampai informasi, namun juga ia memiliki tanggung jawab untuk mengusahakan agar proses belajar mengajar dapat berlangsung dengan optimal dan dipahami oleh peserta didik. Universitas Pendidikan Indonesia (UPI) merupakan salah satu perguruan tinggi negeri yang mencetak guru professional termasuk guru SMK bidang keahlian Teknik Pendingin dan Tata Udara (TPTU). Berkaitan dengan profesi yang akan dijalani para lulusannya, Departemen Pendidikan Teknik Mesin (DPTM) UPI selain harus membekali para calon guru SMK binaannya dengan ilmu pendidikan, DPTM UPI juga harus membekali para calon guru binaannya dengan kompetensi yang relevan dengan SKKNI agar para calon guru tersebut mengajar siswa binaannya di SMK dengan baik.

Kurikulum 2013 di SMK dan kurikulum di DPTM UPI khususnya bidang keahlian Refrigerasi dan Tata Udara (RTU) selama ini belum pernah ditinjau tingkat relevansinya secara mendalam. Mengingat tujuan dari DPTM UPI yaitu untuk mencetak guru SMK seharusnya isi dari kurikulum DPTM UPI ditinjau kesesuaiannya dengan kurikulum di SMK yaitu kurikulum 2013. Idealnya, kurikulum DPTM UPI memiliki relevansi yang baik dengan kurikulum 2013 dan SKKNI agar para calon guru SMK lulusan UPI dapat mencetak siswa SMK yang memiliki kompetensi yang cukup untuk bersaing di dunia kerja sesuai dengan salah satu tujuan pendidikan kejuruan. Penelitian ini bertujuan untuk mengetahui memperoleh data relevansi materi teknik tata udara di DPTM dan di SMK, memperoleh data relevansi materi teknik tata udara di DPTM.dan SKKNI, dan memperoleh data relevansi materi teknik tata udara di SMK dan SKKNI.

Kurikulum mengandung pengertian suatu jarak yang harus ditempuh oleh pelari dari garis start sampai garis finish (Sudjana, 2005). Kurikulum biasa diungkapkan dengan manhaj yang berarti jalan yang dilalui oleh manusia pada berbagai bidang kehidupan. Menurut UU No. 20 Tahun 2003, kurikulum adalah seperangkat rencana dan pengaturan mengenai tujuan, isi, dan bahan pelajaran serta cara yang digunakan sebagai pedoman penyelenggaraan kegiatan pembelajaran untuk mencapai tujuan pendidikan nasional. Kurikulum SMK dimulai pada tahun ajaran 2013/2014 menggunakan kurikulum 2013 
berbasis kompetensi. Kurikulum 2013 dikembangkan berdasarkan beberapa faktor, yaitu tantangan internal, tantangan eksternal, penyempurnaan pola pikir,

Secara garis besar dapat dikemukakan bahwa materi pembelajaran (instructional materials) adalah pengetahuan, keterampilan, dan sikap yang harus dikuasai peserta didik dalam rangka memenuhi standar kompetensi yang ditetapkan. materi pelajaran menempati posisi yang sangat penting dari keseluruhan kurikulum, yang harus dipersiapkan agar pelaksanaan pembelajaran dapat mencapai sasaran. Sasaran tersebut harus sesuai dengan Standar Kompetensi dan Kompetensi Dasar (SKKD) yang harus dicapai oleh peserta didik. Artinya, materi yang ditentukan untuk kegiatan pembelajaran hendaknya materi yang benar-benar menunjang tercapainya standar kompetensi dan kompetensi dasar, serta tercapainya indikator. Materi pembelajaran dipilih seoptimal mungkin untuk membantu peserta didik dalam mencapai standar kompetensi dan kompetensi dasar. Hal yang perlu diperhatikan berkenaan dengan pemilihan materi pembelajaran adalah jenis, cakupan, urutan, dan perlakuan (treatment) terhadap materi pembelajaran tersebut. Agar guru dapat membuat persiapan yang berdaya guna dan berhasil guna, dituntut memahami berbagai aspek yang berkaitan dengan pengembangan materi pelajaran, baik berkaitan dengan hakikat, fungsi, prinsip, maupun prosedur pengembangan materi serta mengukur efektivitas persiapan tersebut (Sanjaya, 2008).

Standar Kompetensi Kerja Nasional Indonesia adalah rumusan kemampuan kerja yang mencakup aspek pengetahuan, keterampilan dan/atau keahlian serta sikap kerja yang relevan dengan pelaksanaan tugas dan syarat jabatan yang ditetapkan sesuai dengan ketentuan undang-undang yang berlaku. Artinya dengan dikuasainya standar kompetensi tersebut oleh seseorang, maka yang bersangkutan akan mampu, mengerjakan suatu tugas atau pekerjaan, mengorganisasikannya agar pekerjaan tersebut dapat dilaksanakan, mengetahui yang harus dilakukan bilamana terjadi sesuatu yang berbeda dengan rencana semula, menggunakan kemampuan yang dimilikinya untuk memecahkan atau melaksanakan tugas dengan kondisi yang berbeda.

\section{METODE PENELITIAN}

Metode penelitian pada dasarnya merupakan cara ilmiah untuk mendapatkan data dengan tujuan dan kegunaan tertentu. Metode penelitian meliputi kegiatan mencari, mencatat, merumuskan, menganalisis sampai menyusun laporannya berdasarkan faktafakta atau gejala-gejala secara ilmiah. Penelitian ini menggunakan metode deskriptif 
analitik. Metode penelitian deskriptif bertujuan untuk mendapatkan gambaran dari fenomena yang ada, yang berlangsung pada saat ini atau saat yang lampau.

Desain atau rancangan kegiatan dalam penelitian ini dilakukan dengan beberapa tahap meliputi pemilihan masalah, studi pendahuluan, merumuskan masalah, memilih pendekatan, dan sumber data. Pemilihan masalah dalam penelitian ini terfokus pada isi kurikulum yaitu materi pembelajaran. Materi pembelajaran yang ada di TRTU DPTM UPI selama ini belum pernah dikaji dengan kebutuhan yang ada di lapangan yaitu sebagai penghasil tenaga pendidik di SMK. Langakah awal adalah dengan melakukan studi pendahuluan mengenai gambaran umum dan tujuan dari masing-masing jenjang pendidikan. Kriteria-kriteria yang muncul dirumuskan agar penelitian lebih terarah yaitu ditinjau dari bahan ajar atau materi yang digunakan selama proses pembelajaran. Pendekatan pada penelitian ini dengan cara menganalisis data yakni mendeskripsikan sebagaimana adanya. Instrumen yang digunakan dalam penelitian ini adalah dokumentasi dan angket (kuesioner).

\section{HASIL PENELTIAN}

Pendeskripsian dilakukan dengan cara menguraikan materi pokok yang ada pada masing-masing subjek penelitian. Subjek penelitian pertama yaitu materi teknik tata udara di DPTM yang terbagi ke dalam lima Mata Kuliah Konsentrasi (MKK) dan lima Mata Kuliah Paket Pilihan (MKPP) (Tabel 1). Subjek penelitian kedua yaitu materi materi teknik tata udara yang ada di SMK yang terbagi kedalam delapan mata pelajaran (Tabel 2). Subjek penelitian ketiga yaitu materi teknik tata udara pada SKKNI yang terbagi kedalam tiga SKKNI.

Tabel 1. Rincian Mata Kuliah Tata Udara di DPTM

\begin{tabular}{ll}
\hline Mata Kuliah Konsentrasi \\
\hline No & Mata Kuliah \\
1 & Teknik Tata Udara \\
2 & Sistem Kelistrikan Tata Udara \\
3 & Sistem Kontrol Tata Udara \\
4 & Kompresor dan Alat Kontrol Tata Udara \\
5 & Pompa dan Cooling Tower \\
Mata Kuliah Paket Pilihan \\
1 & Autocad dan Gambar Tata Udara \\
2 & Ducting, Piping, dan Plumbing \\
3 & Pemeliharaan dan Perbaikan tata Udara \\
4 & Estimasi Beban Tata Udara \\
5 & Perancangan Tata Udara \\
\hline
\end{tabular}


Tabel 2. Rincian Mata Pelajaran Tata Udara di SMK

\begin{tabular}{lll}
\hline No & & \multicolumn{1}{c}{ Mata Pelajaran } \\
\cline { 1 - 1 } 2 & & Sistem dan Instalasi Tata Udara (Kelas XI/Ganjil) \\
3 & & Sistem dan Instalasi Tata Udara (Kelas XI/Genap) \\
4 & & Kontrol Refrigerasi dan Tata Udara (Kelas XI/Ganjil) \\
5 & & Sistem dan Instalasi Tana Udara (Kelas XII/Ganjil) \\
6 & & Sistem dan Instalasi Tata Udara (Kelas XII/Genap) \\
7 & & Kontrol Refrigerasi dan Tata Udara (Kelas XI/Ganjil) \\
8 & & Kontrol Refrigerasi dan Tata Udara (Kelas XI/Genap) \\
\hline
\end{tabular}

Rincian SKKNI Teknik Tata Udara yaitu Memeriksa Fungsi Perangkat Lemari Pendingin/Mesin Pengkondisi Udara; Memelihara Fungsi Perangkat Lemari Pendingin/Mesin Pengkondisi Udara; dan Memperbaiki fungsi Perangkat Lemari Pendingin/Mesin Pengkondisi Udara. Materi yang terdapat pada masing-masing subjek penelitian dijabarkan lebih lanjut. Rincian materi tersebut direlevansikan sesuai dengan tujuan penelitian sehingga diperoleh data relevansi dari ketiga subjek penelitian tersebut. Ketiga subjek penelitian tersebut dinilai telah relevan antara satu sama lain, artinya lulusan DPTM telah memiliki bekal yang cukup untuk mengajar di SMK untuk mencetak siswa lulusan SMK yang memiliki kompetensi sesuai dengan SKKNI.

\section{PEMBAHASAN}

Materi mata kuliah Teknik Tata Udara seluruhnya telah relevan dan mampu memenuhi kebutuhan materi tata udara di SMK dan SKKNI. Materi SKKNI lebih terfokus pada pencapaian skill mengenai pemeriksaan, perawatan, dan perbaikan perangkat lemari pendingin/mesin pengkondisi udara sehingga materi yang bersifat teoritis mengenai dasar tata udara, analisis thermodinamika ataupun perhitungan matematis tidak dibutuhkan pada SKKNI. Hal ini terlihat dari materi mata kuliah Teknik Tata Udara yang memiliki kesesuaian dengan SKKNI merupakan materi-materi yang memerlukan praktikum di lapangan, seperti materi (1) splitt system, (2) single packaged unit, (3) rooftop unit, (4) duct type system, (5) water chiller system, (6) sistem tata udara rumah tinggal, dan (7) sistem tata udara untuk komersil. Keadaan tersebut berbanding terbalik dengan enam materi mata kuliah Teknik Tata Udara yang bersifat teoritis mengenai dasar tata udara, analisis thermodinamika ataupun perhitungan matematis seperti materi (1) human body comfort, (2) siklus udara, (3) siklus pendinginan, (4) psychrometric chart, (5) aplikasi psychrometric chart, dan (6) proses psychrometric, materi tersebut tidak memiliki kesesuaian dengan materi yang dibutuhkan pada SKKNI walaupun materi tersebut 
merupakan materi penunjang yang dibutuhkan untuk memudahkan pemahaman peserta didik dalam teknik tata udara (Wena, 2011).

Seluruh materi mata kuliah Pemeliharaan dan Perbaikan Tata Udara telah relevan dengan materi tata udara di SMK dan juga materi yang dibutuhkan pada SKKNI. Ditinjau secara lebih mendalam, mata kuliah Pemeliharaan dan Perbaikan Tata Udara merupakan mata kuliah yang paling memiliki kesesuaian dengan SKKNI bila dibandingkan dengan mata kuliah lainnya. Hal ini dikarenakan mata kuliah Pemeliharaan dan Perbaikan Tata Udara memiliki fokus yang sama dengan SKKNI yaitu penguasaan skill dalam memeriksa, merawat, dan memperbaiki perangkat mesin pengkondisi udara. Seluruh materi pada mata kuliah Pemeliharaan dan Perbaikan Tata Udara memiliki relevansi dengan materi SKKNI yang relatif banyak. Satu materi mata kuliah Pemeliharaan dan Perbaikan Tata Udara dapat mendukung beberapa materi di SMK dan SKKNI, misalkan materi pemeliharaan condensing unit. Materi pemeliharaan condensing unit merupakan materi yang cukup kompleks dan dapat mewakili beberapa materi di SMK. Hal ini dapat terjadi karena condensing unit merupakan sebuah unit pada sistem tata udara yang di dalamnya terdapat tiga komponen utama sistem tata udara yaitu kompresor, kondenser dan alat ekspansi. Selain itu di dalam condensing unit juga terdapat beberapa komponen tambahan yang digunakan dalam mesin pengkondisi udara. Materi pemeliharaan condensing unit memiliki kesesuaian dengan enam materi tata udara di SMK, yaitu (1) komponen utama sistem tata udara, (2) operasi sistem tata udara, (3) peralatan servis sistem tata udara, (4) pemeliharaan alat penukar kalor pada sistem tata udara, (5) pengontrolan suhu dan tekanan kerja, dan (6) pemeliharaan alat penukar kalor.

Maeri pada mata kuliah Ducting, Piping, and Plumbing tidak memiliki relevansi dengan materi SKKNI. Berdasarkan hasil wawancara dengan dosen pengempu mata kuliah Ducting, Piping, and Plumbing, materi mengenai piping dan plumbing di DPTM tidak dapat diberikan karena keterbatasan waktu perkuliahan dan mengingat materi mengenai ducting dianggap lebih dibutuhkan untuk dikuasai oleh mahasiswa DPTM sehingga materi mengenai ducting diberikan secara mendalam kepada mahasiswa. Hal ini dapat terlihat dari empat belas materi yang terdapat pada mata kuliah ini seluruhnya merupakan materi mengenai ducting. Materi mengenai ducting di SMK tidak dipelajari secara mendalam melainkan hanya sebatas pengenalan secara umum pada materi (1) transmisi dan pendistribusian udara, (2) gambar cerobong udara, dan (3) gangguan yang terjadi pada rangkaian damper udara. Ketiga materi tersebut terbagi ke dalam dua mata pelajaran yaitu 
Sistem dan Instalasi Tata Udara (XII/Ganjil), dan Kontrol Refrigerasi dan Tata Udara (XII/Genap).

Isi materi ataupun kompetensinya, seluruh materi mata kuliah Perancangan Tata Udara seluruhnya telah sesuai dengan materi tata udara di SMK dan tidak memiliki relevansi dengan materi SKKNI. Dari isi materi ataupun kompetensinya, seluruh materi mata kuliah Perancangan Tata Udara seluruhnya telah sesuai dengan materi tata udara di SMK. Materi mengenai perhitungan beban pendinginan tata udara yang di DPTM diwakili oleh materi (1) dasar perhitungan beban tata udara, (2) perhitugan beban pendinginan luar ruangan, (3) perhitungan beban pendinginan dari dalam ruangan, dan (4) perhitungan beban total tata udara, memiliki kesesuaian yang sangat erat dengan dua materi tata udara di SMK, yaitu (1) beban pendinginan ruangan, dan (2) perhitungan beban tata udara. masing-masing materi dari kedua buah subjek penelitian tersebut memiliki kesesuaian baik dari segi isi materi ataupun kompetensi yang dicapainya. Begitu pula pada materi menggambar saluran udara yang memiliki kesesuaian dengan menggambar instalasi cerobong udara. Kedua materi tersebut memiliki kesesuaian hingga pencapaian kompetensinya. Keadaan tersebut berbeda dengan beberapa materi pada mata kuliah Perancangan Tata Udara lainnya seperti materi pemilihan unit tata udara, diagram PH, dan analisis thermodinamika.

Materi pemilihan unit tata udara di DPTM memiliki kesesuaian dengan lima materi tata udara di SMK, yaitu (1) beban pendinginan ruangan, (2) komponen utama sistem tata udara, (3) sistem kontrol otomatis, (4) thermostat, dan (5) pressurestat. Ditinjau secara lebih mendalam, lima materi SMK tersebut sebenarnya hanya merupakan materi penunjang untuk melakukan pemilihan unit tata udara, sehingga bila dilihat dari segi pencapaian kompetensi, materi di SMK belum mencapai pada tingkatan melakukan pemilihan unit tata udara seperti di DPTM. Begitu pula terjadi pada materi diagram PH dan materi analisis thermodinamika. Kesesuaian kedua materi DPTM tersebut dengan materi di SMK hanya terbatas pada segi isi materi karena materi-materi SMK yang memiliki kesesuaian tersebut merupakan materi penunjang ketercapaian kompetensi pada materi diagram PH dan analisis thermodinamika di DPTM.

Seluruh materi pada mata kuliah Pompa dan Cooling Tower tidak memiliki kesesuaian dengan SKKNI. Dari sebelas materi yang terdapat pada mata kuliah Pompa dan Cooling Tower, terdapat tujuh materi pada mata kuliah pompa dan cooling tower yang tidak diperlukan pada kurikulum 2013 SMK. Tujuh materi tersebut yaitu (1) komponenkomponen cooling tower, (2) perhitungan beban cooling tower, (3) prinsip kerja pompa, 
(4) komponen-komponen pompa, (5) perhitungan beban pompa, (6) mengukur temperatur di cooling tower, dan (7) pemasangan pompa pada cooling tower. Hal ini dikarenakan cooling tower di SMK hanya diperkenalkan secara umum dan pembahasannya tidak diperdalam seperti di DPTM, bahkan tidak terdapat satupun materi tata udara di SMK yang membahas mengenai pompa.

Materi pada mata kuliah Sistem Kelistrikan Refrigerasi dan Tata Udara seluruhnya memiliki kesesuaian dengan materi tata udara di SMK ataupun dengan materi SKKNI. Mata kuliah Sistem Kelistrikan Refrigerasi dan Tata Udara memiliki kesesuaian dengan tiga materi SKKNI. Ketiga materi SKKNI tersebut tentunya materi yang memiliki korelasi dengan kelistrikan, yaitu materi (1) pemeriksaan rangkaian kelistrikan mesin pengkondisi udara, (2) pemeriksaan rangkaian kelistrikan mesin pengkondisi udara, dan (3) perbaikan rangkaian kelistrikan mesin pengkondisi udara. Tiga materi SKKNI tersebut dari segi isi materi memiliki relevansi dengan seluruh materi mata kuliah Sistem Kelistrikan Refrigerasi dan Tata udara. Ditinjau secara lebih mendalam, seluruh materi pada mata kuliah Sistem Kelistrikan Refrigerasi dan Tata Udara hanya memiliki kesesuaian dari segi isi materi dengan materi tata udara di SMK, seperti pada materi rangkaian kelisttrikan simple air conditioning. Materi rangkaian kelistrikan simple air conditioning memiliki kesesuaian dengan sembilan materi tata udara di SMK yaitu (1) keselamatan kerja sistem kelistrikan RTU, (2) simbol-simbol listrik, (3) kabel, (4) elektrikal diagram, (5) distribusi tenaga listrik, (6) papan hubung bagi, (7) kabel penghantar, (8) cable duct, dan (9) instalasi AC split.

Seluruh materi pada mata kuliah Autocad dan Gambar Tata Udara tidak memiliki kesesuaian dengan SKKNI. Relevansi materi pada mata kuliah Autocad dan Gambar Tata Udara di DPTM dengan SMK hanya terdapat dari segi isi materi. Autocad tidak dipelajari di SMK karena materi tersebut tidak terdapat pada kurikulum 2013 SMK. Artinya dari segi kompetensi seluruh materi pada mata kuliah Autocad dan Gambar Tata Udara tidak memiliki relevansi dengan seluruh materi tata udara di SMK. Inti dari seluruh materi mata kuliah Autocad dan Gambar Tata Udara sebenarnya adalah membekali mahasiswa dengan skill dengan materi tata udara di SMK dari segi isi materi.

Seluruh materi pada mata kuliah Sistem Kontrol Tata Udara memiliki kesesuaian dari segi isi materi ataupun kompetensi dengan materi tata udara di SMK dan dengan materi pada SKKNI. Seluruh materi pada mata kuliah Sistem Kontrol Tata Udara memiliki kesesuaian secara isi materi dengan tiga materi SKKNI pada tiga kompetensi yang berbeda, materi tersebut yaitu (1) perangkat mesin pengkondisi udara (pada kompetensi 
SKKNI memeriksa perangkat lemari pendingin/mesin pengkondisi udara), (2) perangkat mesin pengkondisi udara (pada kompetensi SKKNI merawat perangkat lemari pendingin/mesin pengkondisi udara), dan (3) perbaikan komponen mesin pengkondisi udara (pada kompetensi SKKNI memperbaiki perangkat lemari pendingin/mesin pengkondisi udara). Secara spesifik, alat kontrol sistem tata udara di SMK diberikan pada materi (1) thermostat, (2) pressurestat, (3) thermal tranduncer/transmister, dan (4) pressure tranduncer/transmister. Seluruh materi pada mata kuliah Sistem Kontrol Tata Udara memiliki kesesuaian dari segi isi materi ataupun kompetensi dengan tujuh materi tata udara di SMK, yaitu (1) thermostat, (2) pressurestat, (3) thermal tranduncer /transmister, (4) pressure tranduncer/transmister, (5) sistem kontrol otomatis, (6) humidistat, (7) sistem kontrol semi otomatis, dan (8) sistem dan komponen tata udara komersial.

Materi pada mata kuliah Kompresor dan Alat Kontrol seluruhnya memiliki kesesuaian dari segi isi materi ataupun dari segi kompetensi dengan materi tata udara di SMK dan SKKNI. Kesesuaian materi mata kuliah Kompresor dan Alat Kontrol terdapat pada tiga materi SKKNI dan pada tiga kompetensi yang berbeda, materi tersebut yaitu (1) perangkat mesin pengkondisi udara (pada kompetensi SKKNI memeriksa perangkat lemari pendingin/mesin pengkondisi udara), (2) perangkat mesin pengkondisi udara (pada kompetensi SKKNI merawat perangkat lemari pendingin/mesin pengkondisi udara), dan (3) perbaikan komponen mesin pengkondisi udara (pada kompetensi SKKNI memperbaiki perangkat lemari pendingin/mesin pengkondisi udara. Terdapat delapan materi mata kuliah Kompresor dan Alat Kontrol yang memiliki relevansi dari segi materi dan segi kompetensi dengan materi tata udara di SMK, materi tersebut yaitu (1) memelihara kompresor berdasarkan jenis kompresor, (2) kompresor reciprocating, (3) kompresor rotary, (4) kompresor sentrifugal, (5) kompresor screw, (6) kompresor scroll, (7) alat kontrol komprsor untuk refrigerasi,dan (8) alat kontrol kompresor untuk tata udara. Sebagai contoh dapat dilihat pada materi kompresor rotary.

Seluruh materi pada mata kuliah Estimasi Beban Tata Udara tidak memiliki kesesuaian dengan materi pada SKKNI. Materi pada mata kuliah Estimasi Beban Tata Udara seluruhnya memiliki kesesuaian dari segi isi materi ataupun kompetensi dengan materi tata udara di SMK. Terdapat lima materi pada mata kuliah Estimasi Beban Tata Udara yang memiliki kesesuaian dari segi isi materi dengan materi tata udara di SMK, yaitu (1) kondisi lingkungan, (2) rancangan tata udara yang akan dikondisikan, (3) menghitung udara supply, (4) menghitung by pass fator, dan (5) pemilihan unit tata udara. 
Sebagai contoh dapat dilihat pada materi menghitung udara supply. Materi menghitung udara supply memiliki kesesuaian dengan dua materi tata udara di SMK, yaitu (1) pemetaan proses tata udara, dan (2) transmisi dan ditribusi udara. Kedua materi tersebut memiliki kompetensi yang berbeda dengan materi menghitung udara supply, namun kedua materi tersebut merupakan materi dasar pendukung ketercapaiannya kompetensi materi menghitung udara supply. Sebelas materi pada mata kuliah Estimasi Beban Tata Udara lainnya memiliki relevansi dari segi kompetensi dengan mteri tata udara di SMK, yaitu materi (1) beban pendinginan dari luar ruangan, (2) beban pendinginan dari peralatan listrik, (3) beban pendinginan dari lampu, (4) beban pendinginan dari manusia, (5) beban pendinginan dari infiltrasi, (6) beban pendinginan dari ventilasi, (7) beban pendinginan dari furniture, (8) menghitung faktor koefisien panas, (9) menghitung beban total pendinginan, (10) pencarian beban puncak pendinginan, dan (11) psychrometric chart.

\section{KESIMPULAN}

Materi tata udara di DPTM seluruhnya telah relevan dengan materi tata udara di SMK. Materi tata udara di DPTM telah relevan dan mampu memenuhi seluruh materi SKKNI Memeriksa Perangkat Lemari Pendingin/Mesin Pengkondisi Udara, Merawat Perangkat Lemari Pendingin/Mesin Pengkondisi Udara, dan Memperbaiki Perangkat Lemari Pendingin/Mesin Pendingin udara. Materi tata udara di DPTM telah relevan dan mampu memenuhi seluruh materi SKKNI Memeriksa Perangkat Lemari Pendingin/Mesin Pengkondisi Udara, Merawat Perangkat Lemari Pendingin/Mesin Pengkondisi Udara, dan Memperbaiki Perangkat Lemari Pendingin/Mesin Pendingin udara.

\section{DAFTAR PUSTAKA}

Kemendiknas. (2013). Permendiknas Nomor 28 Tahun 2009 tentang Standar Kompetensi dan Kompetensi Dasar Kejuruan. Jakarta: Direktorat Jenderal Manajemen Pendidikan Dasar dan Menengah.

Nasution. (2008). Berbagai Pendekatan dalam Proses Belajar Mengajar. Bandung: Bumi Aksara.

Sanjaya. (2008). Strategi Pembelajaran Berorientasi Standar Proses Pendidikan. Jakarta: Kencana.

Sudjana. (2005). Dasar-Dasar Proses Belajar Mengajar. Bandung: Sinar Baru Algesindo.

Wena. (2011). Strategi Pembelajaran Inovatif Kontamporer Suatu Pendekatan Tinjauan Konseptual Operasional. Jakarta: Bumi Aksara. 